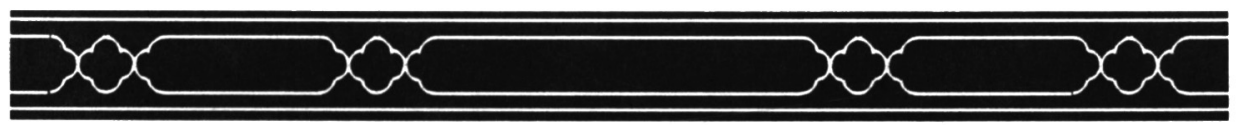

\title{
Middle East Studies Association BULLETIN
}

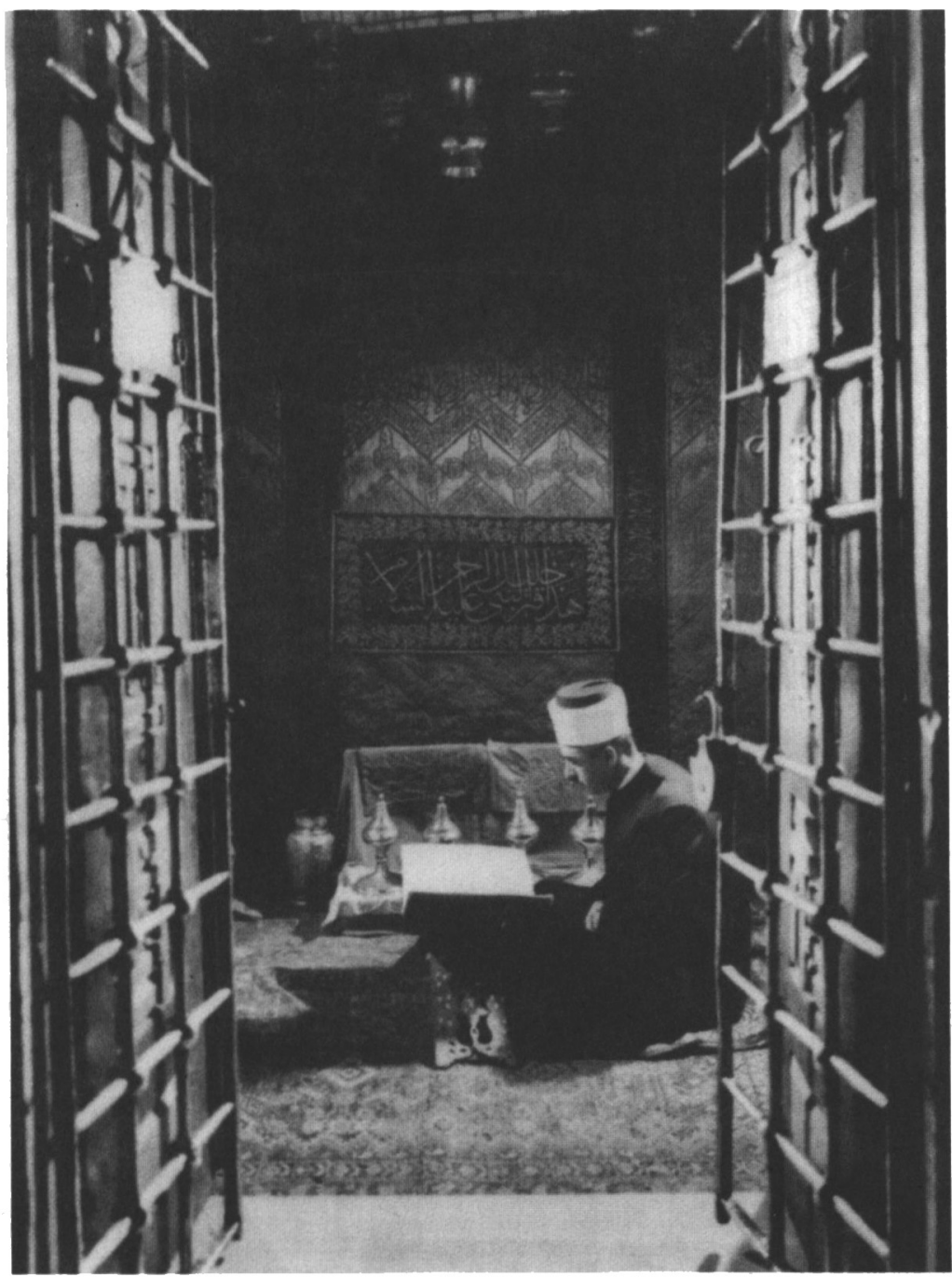


Editor: Jon W. Anderson

Assistant Editors: Terri Edwards, Lett Proctor Clare

Editorial Assistant: Rachel Rumberger

\begin{aligned} & \multicolumn{2}{c}{ Associate Editors } \\ & Economics: Ragui Assaad \\ & IBM Software: William O. Beeman \\ & Audiovisuals: Ellen-Fairbanks D. Bodman \\ & Language \& Literature: Michael Beard \\ & Music \& Recordings: Virginia Danielson \\ & North Africa: John P. Entelis \\ & Iran, Central Asia: Jerrold D. Green \\ & Modern History, Politics: Fred Lawson \\ & Gulf \& Arabian Peninsula: William Ochsenwald \\ & Law \& Religion, Mac Software: A. Kevin Reinhart \\ & Art \& Exhibitions: Marianna S. Simpson \\ & Popular Culture, Folklore: Susan Slyomovics \\ & Pre-Modern History, Philosophy: Tamara Sonn \end{aligned}

COMmUNicATIONS FOR THE EDITOR should be sent to Jon W. Anderson, MESA Bulletin, $200 \mathrm{LCI}$, Catholic University of America, Washington, DC 20064. Phone: (202) 319-5999. Fax: (202) 319-6267. Internet: mesabul@cua.edu.

Tables of contents, notes research \& teaching resources, lists of recent conferences and books in Middle East studies are available on the MESA Bulletin Gopher site (at gopher.cua.edu) or via World Wide Web connection to URL: gopher://vmsgopher.cua.edu. :70/11gopher_root_mesabul:[000000]

Books, Software, Recordings and Audiovisual Material for Review should be sent to the MESA Bulletin, Life Cycle Institute, Catholic University of America, Washington, DC 20064 Books and other materials received for review are listed in the MESA Newsletter.

The Middle East Studies Association Bulletin is a biannual publication of the Middle East Studies Association of North America, Inc., issued in July and December. Views expressed in the Bulletin are those of the authors and do not necessarily represent those of the Association.

( 1995 by the Middle East Studies Association of North America, Inc.

Printed in the United States of America

Distributed by the Cambridge University Press

ISSN 0026-3184

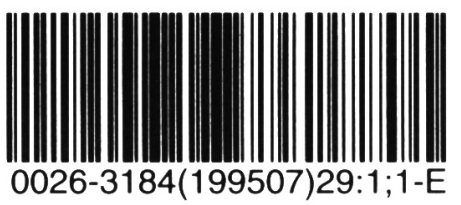




\section{Middle East Studies Association BULLETIN}

Volume $29 \bullet$ Number 1

July 1995

Is There a Future for Middle East Studies? (1994 MESA Presidential

Address) RASHID KHALIDI . . . . . . . . . . . . . . . . . 1

Erasing the Past: The Destruction of Libraries and Archives in

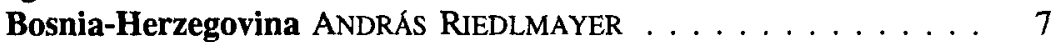

Turks in Germany: Overview of the Literature JENNY B. WHITE . . . 12

Musics of Algeria: Selected Recordings DWIGHT REYNOLDS $\ldots \ldots \ldots 16$

Islamic Economics: The Surest Path? ARUN KAPIL . . . . . . . . . . . 22

Arab Astronomy, Recovered Renaissance C.S.F. BURNETT . . . . . . 25

Malcolm H. Kerr Dissertation Award Competition, $1994 \ldots \ldots . .28$

Albert Hourani Book Award . . . . . . . . . . . . . . . 30

Research \& Teaching Resources . . . . . . . . . . . . . . . . 32

Gophers \& Other Information Servers $\ldots \ldots \ldots \ldots \ldots \ldots$

New E-mail Discussion Lists . . . . . . . . . . . . . . . . . . . . 34

Updates . . . . . . . . . . . . . . . . . . . . . 36

Scholarly Societies, Periodicals \& Publication Series . . . . . . . . 37

\section{Modern History \& Politics: Maghreb}

Julia A. Clancy-Smith, Rebel and Saint: Muslim Notables, Populist Protest, Colonial Encounters (Algeria and Tunisia, 1800-1904), (John Ruedy) . . . . . . . . . . . . . . . . . . . . . . . . 41

MICHAEL M. LASKIER, North African Jewry in the Twentieth Century:

The Jews of Morocco, Tunisia, and Algeria (Fred Astren) . . . . . 42

HARVEY E. GoldBerg, The Book of Mordekhai: A Study of the Jews of

Libya. Selections from the Higgid Mordekhai of Mordechai

Hakohen (Norman A. Stillman) _. . . . . . . . . . . . . .

Ali ABDTILlATIF AHMIDA, The Making of Modern Libya: State

Formation, Colonization, and Resistance, 1830-1932 (Weston F.

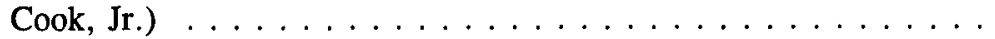

Modern History \& Politics: Central Middle East

KIRK J. BEATTIE, Egypt During the Nasser Years: Ideology, Politics, and Civil Society (Vernon Egger) . . . . . . . . . . . . . . . . . . 
Mohamed Abdel Ghani El-Gamasy, The October War: Memoirs of

Field Marshal El-Gamasy of Egypt (Avraham Sela) . . . . . . . . . 46

EbBA Augustin, ed. Palestinian Women, Identity and Experience

(Bassam K. Abed) . . . . . . . . . . . . . . . . . . . . . . . .

Shaul EPHRAIM CoHEN, The Politics of Planting: Israeli-Palestinian

Competition for the Control of Land in the Jerusalem Periphery

(Garth Katner) . . . . . . . . . . . . . . . . . . . . . . . . . . . .

Robert B. Satloff, From Abdullah to Hussin: Jordan in Transition

(Eugene Rogan)

Youssef M. CHOUEIRI, ed. State and Society in Syria and Lebanon

(David Waldner) ... . . . . . . . . . . . . . . . . . 50

Canan Balkir \& Allan M. Williams, ed. Turkey and Europe

(Marcie J. Patton)

ANN ZWICKER KERR, Come With Me from Lebanon: An American

Family Odyssey (Helena Cobban)

Ellis GoldBerg, Reşat Kasaba \& Joel S. Migdal, ed. Rules and

Rights in the Middle East: Democracy, Law, and Society (Glenn E.

AzIZ AL-AZMEH, Islams and Modernities (Irene L. Gendzier) . . . . . . 55

FATIMA MERnissi, Islam and Democracy: Fear of the Modern World

(Marilyn Booth) . . . . . . . . . . . . . . . . . . . . . . 56 56

Heather DeEgan, The Middle East and Problems of Democracy (Glenn

E. Robinson) . . . . . . . . . . . . . . . . . 57

DaN TschIRGI, ed. The Arab World Today (Joe Stork) . . . . . . . . . . . 58

BASSAM TIBI, Conflict and War in the Middle East, 1967-91: Regional

Dynamic and the Superpowers (Tareq Y. Ismael) . . . . . . . . . . . 5

LILlian CRAIG HARRIS, China Considers the Middle East (Andrew C.

Hess $\ldots \ldots \ldots \ldots \ldots \ldots \ldots$

\section{Modern History \& Politics: Gulf \& Arabian Peninsula}

HAIM SHEMESH, Soviet-Iraqi Relations, 1968-1988: In the Shadow of the

Iraq-Iran Conflict (Ahmad A. R. Shikara) .

AMATZIA BARAM \& BARRY RUBIN, ed. Iraq's Road to War (Robert D.

Burrowes)

JEHAN S. RAJAB, Invasion Kuwait: An Englishwoman's Tale (Jason

Thompson) ........................ 63

Geoff Simons, Iraq: From Sumer to Saddam (Salwa Ismail) . . . . . . . . 64

W. ThOM Workman, The Social Origins of The Iran-Iraq War (Pete W.

Moore)

TAREQ Y. ISMAEL \& JACQUELINE S. ISMAEL, The Gulf War and the New

World Order (Paul Kingston)

Ronnie Miller, Following the Americans to the Persian Gulf: Canada,

Australia and the Development of the New World Order (Rex

Brynen) .........................668

RICHARD SCHOFIELD, ed. Territorial Foundations of the Gulf States

(Malcolm C. Peck) . . . . . . . . . . . . . . . . . . . . 
Joseph Kostiner, The Making of Saudi Arabia, 1916-1936: From Chieftaincy to Monarchical State (Rosemarie Said Zahlan) . . . . . 70

JosePH A. KeCHICHIAN, ed. Political Dynamics and Security in the Arabian Peninsula Through the 1990s (Rear Admiral Harold J. Bernsen, USN (RET))

\section{Modern History \& Politics: Iran \& Central Asia}

H.B. PAKSOY, ed. Central Asia Reader: The Rediscovery of History (Adeeb Khalid) . . . . . . . . . . . . . . . . . . . . 72

STEPHEN FREDERICK DALE, Indian Merchants and Eurasian Trade, 1600-1750 (Rudi Mathee) . . . . . . . . . . . . . . . . 73

Marvin G. WEInBAUM, Pakistan and Afghanistan: Resistance and Reconstruction (Kamal Ali Beyoghlow) . . . . . . . . . . . . . 74

BARNETT R. RuBIN, The Fragmentation of Afghanistan: State Formation and Collapse in the International System (Richard S. Newell) . . . . 75

\section{Economic \& Geography}

ABbaS AlNASRAWI, The Economy of Iraq: Oil, War, Destruction of Development and Prospects, 1950-2010 (Robert Looney) . . . . . . .

THIERRY COVILLE, ed. L'économie de l'Iran islamique: entre l'état et le marché (Farhad Nomani) . . . . . . . . . . . . . . . . . . . 7

Peter Rogers \& PETER Lydon, ed. Water in the Arab World:

Perspectives and Prognoses (Donald Malcolm Reid)

\section{History \& Historiography before 1900}

AlbREcht Noth, The Early Arabic Historical Tradition: A Source-

Critical Study (Muhammad Qasim Zaman) . . . . . . . . . . . . . . 80

AIMAN IBRAHIM, Der Herausbildungsprozeß des arabisch-islamischen Staates (Paul M. Cobb) . . . . . . . . . . . . . . . . . . 8

G. REX SMITH, trans. \& annot. The History of al-.Tabari, Vol XIV: The Conquest of Iran (M. Reza Afshari) . . . . . . . . . . . . . . . . . . . . 81

Claude AdDAS, Quest for the Red Sulphur: The Life of Ibn 'Arabi

(Gabriel Lahood) . . . . . . . . . . . . . . . . . . . . . . 82

FARHAD DAFTARY, The Assassin Legends: Myths of the Isma ilis (James E. Lindsay) . . . . . . . . . . . . . . . . . . . . . . . 83

ClifFord EDMOND BosworTH, The History of the Saffarids of Sistan and the Maliks of Nimruz (247/861 to 949/1542-3) (M.A.J. Beg) . .

CARL F. PETRY, Twilight of Majesty: The Reigns of the Mamlük Sultans

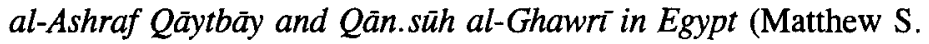
Gordon)

WESTON F. COOK, JR., The Hundred Years War for Morocco:

Gunpowder and the Military Revolution in the Early Muslim World (Jacob Abadi) . . . . . . . . . . . . . . . . . . . .

RONALD C. JENNINGS, Christians and Muslims in Ottoman Cyprus and 
the Mediterranean World, 1571-1640 (Daniel J. Sahas) . . . . . . 88

RIKA GYSElEn, ed. Circulation des Monnaies, des Marchandises et des

Biens, (Muhammad Al-Faruque) . . . . . . . . . . . . . . . . . . 89

Doris BEHRENS-ABOUSEIF, Egypt's Adjustment to Ottoman Rule:

Institutions, Waqf \& Architecture in Cairo (16th \& 17th Centuries)

(Daniel Crecelius) . . . . . . . . . . . . . . . . . . . . . . 90

R.S. O'FAHEY, comp. The Writings of Eastern Sudanic Africa to c. 1900

(Jay Spaulding) . . . . . . . . . . . . . . . . . . 91

RAOUl CURIEl \& RIKA GySELEN, ed. Itinéraires d'Orient, Hommages à

Claude Cahen (Charles Issawi) . . . . . . . . . . . . . . . . . 92

\section{Art History \& Architecture}

Milo Cleveland Beach, The New Cambridge History of India: Mughal and Rajput Painting (Amina Okada) . . . . . . . . . . . . . . .

ROBERT HILlENBRAND, ed. The Art of the Saljüks in Iran and Anatolia:

Proceedings of a Symposium held in Edinburgh in 1982 (Scott

Redford)

MichaEl MeinecKe, Die Mamlukische Architektur in Ägypten und

Syrien (648/1250 bis 92311517) (Marianne Barrucand) . . . . . . 95

Marie LuKens SwiETOCHOWSKI \& STEFano CaRboni, with essays by

A. Morton \& Tomoko Masuya, Illustrated Poetry and Epic Images:

Persian Painting of the 1330s and 1340s (Eleanor Sims) . . . . . . 97

Yves PORTER, Peinture et Arts du Livre: Essai sur la littérature

technique indo-persane (David J. Roxburgh) _ . . . . . . . 98

Anthropology, Sociology, Folklore

LEE HoRNE, Village Spaces: Settlement and Society in Northeastern Iran

(Patty Jo Watson) . . . . . . . . . . . . . . . . . . . . . . . 99

BETH BARON, The Women's Awakening in Egypt: Culture, Society and the Press (Kirsten E. Schulze) . . . . . . . . . . . . . . . . 100

Valentine M. Moghadam, ed. Identity Politics \& Women: Cultural Reassertions and Feminisms in International Perspective (Julie Peteet) . . . . . . . . . . . . . . . . . . . . . . . 101

URSUla KINGSMILl HART, Behind the Courtyard Door: The Daily Life of Tribeswomen in Northern Morocco (Susan Schaefer Davis) . . . 102

JOANNA KAI, ed. Food for Our Grandmothers: Writings by Arab-American and Arab-Canadian Feminists (Diana Abu-Jaber) . . 103

PAUL DRESCH, Tribes, Government, and History in Yemen (Alexander Knysh) . . . . . . . . . . . . . . . . . . . . . . . . 104

DAPHNE TsImHonI, Christian Communities in Jersualem and the West Bank Since 1948: An Historical, Social, and Political Study (LaVerne Kuhnke) . . . . . . . . . . . . . . . . 105

JoHN H. MELKon Rose, Armenians of Jerusalem: Memories of Life in Palestine (LaVerne Kuhnke) . . . . . . . . . . . . . . . . . . 107 BOZKURT GÜVENÇ, Türk Kimliği: Kültürr Tarihinin Kaynaklan (Carter 
Vaughn Findley) . . . . . . . . . . . . . . . . . . . 107

SANDRA SHAW, ed. Doctor Mary in Arabia: Memoirs by Mary Bruins

Allison, MD (Eleanor Abdella Doumato) . . . . . . . . . . 108

LeWIS Pyenson, Civilizing Mission: Exact Sciences and French Overseas

Expansion, 1830-1940 (Dale F. Eickelman) . . . . . . . . . . . 109

FRANCES TRIX, Spiritual Discourse: Learning with an Islamic Master

(Walter Feldman) . . . . . . . . . . . . . . . . 111

\section{Religious \& Legal Studies}

H.T. NORRIS, Islam in the Balkans: Religion and Society Between

Europe and the Arab World (Michael A. Sells) . . . . . . . . . . 112

RICHARD W. BULliET, Islam: The View from the Edge (Mangol Bayat) . . 113

F.E. PETERS, A Reader on Classical Islam (Nicholas Heer) . . . . . . . 114

YA.HYA IBN SHARAF AL-NAWAWI, Al-Maqasid: Imam Nawawi's Manual

of Islam (Devin J. Stewart) . . . . . . . . . . . . . . . . 115

ALI DASHTI, 23 Years: A Study of the Prophetic Career of Mohammad

(Linda S. Walbridge) . . . . . . . . . . . . . . . . . 116

LEONARD LEWISOHN, ed. The Legacy of Mediaeval Persian Sufism

(Jamal J. Elias) . . . . . . . . . . . . . . . . . . . . . . 117

BRUCE B. LAWRENCE, trans. \& annot. Morals for the Heart:

Conversations of Shaykh Nizam ad-din Awliya (Alan A. Godlas) . . 118

BARBARA FREYER STOWASSER, Women in the Qur'an, Traditions and

Interpretation (Tamara Sonn) . . . . . . . . . . . . . . . 119

\section{Language \& Literature}

Grace Martin Smith, The Poetry of Yunus Emre, A Turkish Sufi Poet

(Talat Sait Halman) . . . . . . . . . . . . . . . . . . . 120

HADRAT 'ABD AL-QADIR AL-JILANI, The Secret of Secrets (Bruce B.

Lawrence) . . . . . . . . . . . . . . . . . . . . . . . . . . . 121

Michael A. Sells, trans. Desert Tracings: Six Classic Arabian Odes,

'Alqama, Shänfara, Labid, 'Antara, Al-A'sha and Dhu al-Rúmma

(Adel S. Gamal) . . . . . . . . . . . . . . . . . . . . . . . . 122

VICTORIA ROWE HOLBROOK, The Unreadable Shores of Love: Turkish

Modernity and Mystic Romance (Talat Sait Halman) . . . . . . . . 124

SADDEKA AREBI, Women and Words in Saudi Arabia, The Politics of

Literary Discourse (Eleanor A. Doumato) . . . . . . . . . . 125

SAMIA MEHREZ, ed. Egyptian Writers Between History and Fiction:

Essays on Naguib Mahfouz, Sonallah Ibrahim \& Gamal al-Ghitani

(Roger Allen) . . . . . . . . . . . . . . . . . . . . . . . 126

KENETH WHITEHEAD \& KEVIN ANDERSON, trans. For Rushdie: Essays

by Arab and Muslim Writers in Defense of Free Speech (Miriam

Cooke) . . . . . . . . . . . . . . . . . . . . . . . . 127

OUt El Kouloub, Ramza (Beth Baron) . . . . . . . . . . . . . . . 128

KARIN C. RYDING \& ABDELNOUR ZAIBACK, Formal Spoken Arabic, Fast

Course (Rkia Elaroui Cornell) 
IbN Kamal PaSha, Ta 'Riib Al-Kalima Al-a'Ghamiyyay (Dr. Lutz

Edzard) . . . . . . . . . . . . . . . . . . . . . . 130

\section{Reference Works}

EDNa LaUden \& LioRa WeInBaCh, Multi-Dictionary, Hebrew-HebrewEnglish, English-Hebrew (Sadok Masliyah) . . . . . . . . . 131

Michael E. Bonine, Eckart Ehlers, Thomas KraffT \& George STÖBER, eds. The Middle Eastern City and Islamic Urbanism: An Annotated Bibliography of Western Literature (Jon W. Anderson) . . 132

LUTZ ILISCH, Sylloge Numorum Arabicorum Tübingen: Palästina IVa Bilād ă̌s̆sām I (Michael L. Bates) . . . . . . . . . . . . . . . . . 133

Briefly Noted $\ldots \ldots \ldots \ldots \ldots \ldots \ldots \ldots \ldots \ldots \ldots \ldots$

\section{Audiovisuals}

Quest for Change: Civil Society in the Middle East (Herbert L. Bodman) . 137 Islamic Fundamentalism and Democracy (Vernon Egger) . . . . . . . . 138 Not Without My Veil: Women in Oman (Aida A. Bamia) . . . . . . . . . . 139 Terrorism and Kebab (Carrie Rosefsky Wickham) . . . . . . . . . . 140 Muslims in France (Bruce B. Lawrence) . . . . . . . . . . . . . . . 141 Muslims in Bulgaria (Bruce B. Lawrence) . . . . . . . . . . . . . . 142

\section{Software \& Multimedia}

The Sono-Qur'an, recited by SHEIKH MAHMUD SADIQ AL-MINSHAWI

(Sherman A. Jackson) . . . . . . . . . . . . . . . . . . . . . 143

Al-Qur'an Al-Kareem (Sinan Antoon) . . . . . . . . . . . . 145

TextPert 3.7 Arabic (Joseph N. Bell, Peter Zemanek) . . . . . . . . . . . 146

al-Qari' al-Ali (Joseph N. Bell, Peter Zemanek) . . . . . . . . . . . . . 146

Corrections \& Apologies . . . . . . . . . . . . . . . . . . . . . . . . 148

Cover: Haram al-Ibrahim, Hebron. Photo: Manoug. Courtesy of the Fine Arts Library, Harvard University. 